TARN Working Paper

11/2017

August 2017

\title{
Constitutional limits to the EU agencies' external relations
}

Merijn Chamon and Valerie Demedts 
The Academic Research Network on Agencification of EU Executive Governance (TARN) is a Jean Monnet Network co-funded by the Erasmus+ programme of the European Union.

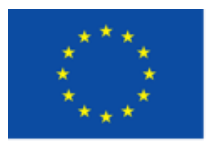

Co-funded by the

Erasmus+ Programme

of the European Union

e twitter.com/EUtarn

f facebook.com/TheAcademicResearchNetwork

TARN Working Papers (online) | ISSN: 2464-3270

http://tarn.maastrichtuniversity.nl/publications/tarn-working-papers/

\section{Editorial team:}

Giacinto della Cananea, Law School, University of Rome Tor Vergata Morten Egeberg, ARENA Centre for European Studies, University of Oslo Michelle Everson, School of Law, Birkbeck College Johannes Pollak, Institute for Advanced Studies/Webster University Vienna Jarle Trondal, ARENA Centre for European Studies, University of Oslo Ellen Vos, Maastricht Centre for European Law, Maastricht University

\section{Series editors:}

Morten Egeberg and Jarle Trondal

Issued by:

ARENA Centre for European Studies

University of Oslo

P.O. Box 1143 Blindern

0318 Oslo, Norway

www.arena.uio.no

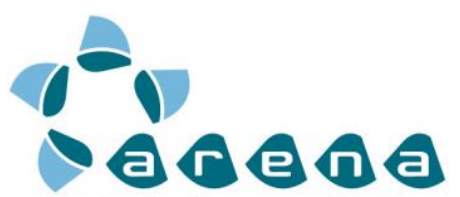

Centre for European Studies University of Oslo 


\section{Constitutional limits to the EU agencies' external relations}

\section{Merijn Chamon and Valerie Demedts}

\section{Abstract}

The present working paper traces the constitutional limits to the external action of EU agencies. The paper argues that these limits are a combination of the general constitutional limits on EU action, the institutional balance in EU external relations (as most recently clarified by the Court of Justice in Case C-66o/13) and the specific limits to EU agency action (the Meroni doctrine and the Common Approach on decentralised agencies). The paper further finds that the EU legislature has devoted insufficient attention to these limits when defining the agencies' external powers in their establishing regulations. The paper identifies a possible way forward to ensure effective external action by $\mathrm{EU}$ agencies while respecting the relevant constitutional limits.

\section{Keywords}

Constitutional limits, EU agencies, external action, institutional balance

\section{Authors}

Merijn Chamon, post-doctoral assistant at the Ghent European Law Institute, Ghent University and Visiting Professor at the University of Antwerp, Belgium

Valerie Demedts, academic assistant and $\mathrm{PhD}$ researcher at the Ghent European Law Institute, Ghent University, Belgium 


\section{Introduction ${ }^{1}$}

In order to effectively fulfil their mission, EU agencies need to develop and maintain contacts with international counterparts, be it international organisations or third country authorities. Indeed, most of the agencies' establishing acts instruct the relevant agency to cooperate internationally and recent scholarship has charted the actual external action which EU agencies engage in. ${ }^{2}$ However, the extent to which EU agencies can act in the international sphere should be circumscribed by the general constitutional limits that apply to any exercise of power by the agencies. The purpose of this paper is to identify these constitutional limits, focusing on the principles of conferral, proportionality, institutional balance and the Meroni doctrine. Still, what makes the agencies' external activities stand out from their internal activities is that the relevant institutional balance (in the area of the EU's external relations) is defined in a rather detailed manner in the EU Treaties and is a perpetual boon of contention between the EU institutions themselves.

This even more so in recent times, since the entry into force of the Lisbon Treaty has put in motion a series of inter-institutional conflicts before the Court of Justice of the European Union in which the precise definition of the institutional balance in the area of the EU's external relations has been at issue. Since the latter is also a relevant limit for agency action, the relevance of these cases for the EU agencies, in so far as the Court actually clarifies the institutional balance, is evident. One particular topic in this context is the question whether the autonomous EU legal order recognizes so-called administrative agreements and under which conditions these might be resorted to.

The present paper scrutinizes a number of recent developments regarding the constitutional limits of external agency action. It attempts to fill in some of the gaps left by the 2012 Common Approach on Decentralised Agencies, ${ }^{3}$ which basically limited itself to stating that EU Agencies may not commit the Union or the Member States. By doing so, the Common Approach did not devote enough attention to the possibilities for EU agency external action. Instead it merely operationalized the principle of loyal cooperation by prescribing a continuous dialogue between the Commission and the agencies, ignoring other constitutional limits.

The recent developments on which the paper will focus are legislative practice as well as decisions of the Court. As regards the latter, the decision of the Court in Council $v$

\footnotetext{
${ }^{1}$ We would like to thank prof. dr. A. Ott and the participants to the TARN Florence Conference, at which a draft of this paper was presented on 10 November 2016, for their valuable comments. Any errors or omissions remain those of the authors.

2 F. Coman-Kund (2015) European Union Agencies as global actors - a legal study of the European Aviation Safety Agency, Frontex, and Europol, Universitaire Pers Maastricht.

3 Council Note on 'Evaluation of European Union Agencies - Endorsement of the Joint Statement and Common Approach', Brussels, 18 June 2012, 11450/12, available at http://register.consilium. europa.eu/doc/srv?l=EN\&f=ST\%2011450\%202012\%20INIT (last accessed 3 October 2016). The text of the Common Approach is mentioned in Annex II to the Note.
} 
Commission is noteworthy for the issue of administrative agreements since the Council in that case questioned the Commission's autonomy to conclude non-binding agreements on behalf of the EU. 4 As will be discussed, this case is an important addition to the two France $v$ Commission cases. 5 The possibilities for EU agency external action are then outlined by taking into account both the general limits to agencies' empowerments and the specific institutional balance in EU external relations.

\section{A deficient framework: the Common Approach on decentralised agencies}

To remedy the ad hoc approach to agencification, the EU institutions in 2012 adopted a general set of guiding principles - a 'Common Approach' - to make the EU decentralised agencies' governance and functioning more coherent, effective, efficient and accountable. ${ }^{6}$

As regards the agencies' external relations the Common Approach contains several guiding principles. It provides that agencies cooperating at the international level should establish a strategy for their external relations in their work programme. An agency's external relations' strategy and activities must therefore be approved by its Management Board. Moreover, working arrangements with the relevant Commission Directorates General (DGs) should ensure that agencies stay within their mandate. Most importantly, agencies should not be seen as representing the EU or committing the EU internationally. Finally, the consistency of the EU's external policy should be ensured by an early exchange of information between the agency, the Commission and the Union delegations.

While these elements show that the Common Approach (rightly) emphasizes adherence to the principle of sincere cooperation (between EU actors) to ensure that the EU agencies' external action integrates smoothly into the EU's external action, this is arguably insufficient to ensure compliance with the general constitutional limits on the agencies' external relations.

These limits are essentially twofold: the general principles of EU law, which apply to any EU action, and the specific principles governing the agencies' functioning. In what follows we will mainly focus on the principles of conferred powers and institutional balance, as far as general principles goes, and the Meroni doctrine, i.e. the constitutional limit specific to EU agencies.

\footnotetext{
4 Judgment of 28 July 2016, Council $v$ Commission, C-66o/13, EU:C:2016:616.

5 Judgment of 9 August 1994, France $v$ Commission, C-327/91, EU:C:1994:305 (France v Commission I); Judgment of 23 March 2004, France $v$ Commission, C-233/02, EU:C:2004:173 (France v Commission II).

${ }^{6}$ European Commission, Press Release, 'Breakthrough as EU institutions agree Common Approach on agencies', Brussels, 13 June 2012, available at http://europa.eu/rapid/press-release_IP-12-604 _en.htm (last accessed 3 October 2016); https://europa.eu/european-union/about-eu/agencies/ overhaul_en (last accessed 3 October 2016).
} 


\section{Meroni applied to EU decentralised agencies' external relations}

In the 2014 Short-selling case, 7 the Court of Justice confirmed that the exercise of public power by the EU decentralised agencies is governed by the, reinterpreted, Meroni doctrine. Since the Court made this clarification in general terms, it may be assumed that Meroni applies whenever an agency acts in a binding manner (see below), regardless whether it does so internally or on the international plane.

The Court has not been explicit about the ratio of the Meroni doctrine, nor has consensus been reached on this ratio or the constitutional values it is intended to protect in legal doctrine. For the purposes of this paper it will be assumed that Meroni aims to ensure that the Treaty-ordained institutions exercise effective control over the EU's functioning. While the Meroni doctrine is often confused with the principle of institutional balance, ${ }^{8}$ it cannot be assumed thereunder, as the latter is mainly concerned with safeguarding the prerogatives of the institutions. 9

The Meroni doctrine as presently defined subsequently raises the question as to when an agency is sufficiently 'controlled'. Originally the Court required i.a. that only 'clearly defined executive' powers are granted. ${ }^{10}$ Following Short-selling it is now sufficient that 'precisely delineated' powers have been granted to the agency. ${ }^{11}$ Although caution is in order when general conclusions are drawn from Short-selling, a power may be said to be 'precisely delineated' under that jurisprudence when (i) the conferral of powers is exceptional, e.g. entrusting a task to an agency may be justified in light of the technical nature of the task, (ii) the agency's powers are embedded in decision-making procedures involving other actors, i.e. the agency should not be able to make decisions autonomously, and (iii) the agency acts pursuant to pre-defined criteria. ${ }^{12}$

\footnotetext{
7 Judgment of 22 January 2014, UK $v$ Parliament and Council, Case C-270/12, EU:C:2014:18 (Short-selling).

${ }^{8}$ See M. Chamon (2016) EU Agencies: Legal and Political Limits to the Transformation of the EU Administration, Oxford: Oxford University Press, pp. 229-230.

9 This is because the institutional balance plays between the EU institutions. In theory it might be possible to empower an agency without undermining any of the institutions' prerogatives (i.e. in conformity with the institutional balance) but this would not necessarily mean that the agency is also 'controlled'.

${ }^{10}$ See Judgment of 13 June 1958, Meroni $v$ High Authority, 9/56, EU:C:1958:7, p. 152. In the French version of the judgment the Court referred to 'des pouvoirs d'exécution exactement définis.' See p. 44. ${ }^{11}$ Adamski is one of the few who notes the repercussion of the Court's change in emphasis from 'clearly defined executive' to 'precisely delineated' powers, see D. Adamski, 'The ESMA Doctrine: A Constitutional Revolution and the Economics of Delegation', 39 ELRev. 6, 2014, p. 827.

${ }^{12}$ See M. Chamon, op. cit., p. 247. Coman-Kund draws a different set of criteria from Short-selling. They are not taken over because they integrate institutional balance concerns in the Meroni doctrine and because they still refer to the merely executive nature of agencies' powers see F. Coman-Kund, op. cit., p. 89 .
} 


\section{Requirements flowing from the principle of conferred powers}

The principle of conferred powers requires that any act adopted by the EU (institutions, bodies, offices and agencies) finds a legal basis (explicit or implied) in the Treaties. An explicit Treaty legal basis allowing the EU decentralised agencies to conclude agreements or arrangements is lacking. Because they are not institutions, the agencies also do not come under Article 335 TFEU which would otherwise allow them to represent the EU by virtue of their administrative autonomy. In so far as Article 220(2) TFEU only refers to the Commission and the High Representative, the EU agencies would also be barred from relying on Article 220(1) TFEU to maintain 'relationships as are appropriate with other international organisations'.

As a rule then, the power of EU agencies to enter into arrangements or agreements with international counterparts should be explicitly foreseen in the agencies' establishing acts (or other EU legislative acts). ${ }^{13}$ Although not explicitly foreseen by the Treaty legal basis, it may be assumed that this power comes within the EU legislature's broad discretion. Indeed, as regards Article 114 TFEU, the legal basis most relied upon by the EU legislature in recent agencification, the Court of Justice has a long standing jurisprudence finding that 'Article 114 TFEU confers on the EU legislature a discretion as regards the method of approximation most appropriate for achieving the desired result, in particular in fields with complex technical features' ${ }^{14}$ More generally then, if the EU legislature believes that granting an agency the power to conclude arrangements or agreements is necessary for the agency to fulfil its mandate and if the latter is covered by the Treaty legal basis relied upon, then so will be the agency's power to enter into international relations.

\section{Developments in EU case law on administrative agreements in the international and EU legal order}

Before embarking on an analysis of the case-law clarifying the principle of institutional balance in EU external action, the particular issue of 'administrative agreements' must be addressed. In several jurisdictions a distinction is made between important

\footnotetext{
13 The exception here would be when another, explicitly granted, power requires the agency to conclude an arrangement with a third country or an international organization. The ECHA regulation for instance does not explicitly foresee that ECHA can conclude international agreements or (working) arrangements. However, its Article 77(2)l does allow it to provide technical or scientific support to improve the cooperation between the EU, its Member States and third countries/international organizations. If a working arrangement between the ECHA and the latter is necessary for the ECHA to provide this support, this should evidently be permissible. Similarly, see Articles 106, 107, 120 of the ECHA regulation.

14 See Judgment of 4 May 2016, Poland v. Parliament and Council, Case C-358/14, ECLI:EU:C:2016:323, para. 68.
} 
agreements requiring legislative approval on the one hand and less important agreements which may be ratified by the executive on the other hand. ${ }^{15}$

Despite widespread use, so-called 'administrative agreements' are surrounded by legal ambiguity. ${ }^{16}$ The EU Treaties explicitly foresee only a limited set of international cooperation instruments, spelling out at the same time the procedures to be followed to adopt those instruments. ${ }^{17}$ In the Union's daily external practice, however, the institutions also make use of instruments that do not have a formal Treaty base and for which, subsequently, no separate procedural rules are laid down. ${ }^{18}$

For the EU this issue acquires constitutional importance in light of the principle of conferred powers, according to which 'the Union shall act only within the limits of the competences conferred upon it by the Member States in the Treaties.' ${ }^{19}$ Still, in order not to paralyze the EU's external action, the Court has not inferred from this provision that only those instruments explicitly provided for may be relied upon by the EU. As such, the Court has accepted that the EU may also adopt unilateral binding declarations, ${ }^{20}$ may intervene before an international jurisdiction, ${ }^{21}$ may issue declarations of acceptance of a third country's accession to international conventions, ${ }^{22}$ etc. Still, the lack of explicit Treaty basis for these instruments results in ambiguity concerning their legal nature and effects. ${ }^{23}$ This is problematic given that the EU institutions, and the Commission in particular, ${ }^{24}$ require recourse to these instruments in order to pursue an effective EU external relations policy. ${ }^{25}$

\footnotetext{
${ }^{15}$ F. Morrison, 'Executive Agreements', in: Max Planck Encylopaedia of Public International Law, http://opil.ouplaw.com (last accessed 5 August 2016).

16 F. Coman-Kund, op. cit., p. 147.

${ }_{17}$ See for instance Article 218 TFEU, which contains i.a. the procedure to be followed when concluding association agreements.

${ }^{18}$ F. Coman-Kund, op. cit., p. 102.

19 See Article 5 (2) TEU.

${ }^{20}$ See Judgment of 26 November2014, Parliament and Commission v. Council, Joined Cases C103/12 and C-165/12, EU:C:2014:2400.

${ }^{21}$ See Judgment of 6 October 2015, Council $v$. Commission, Case C-73/14, EU:C:2015:663. On the competence to instigate proceedings before a court of a third country, see Judgment of 15 January 2003, Philip Morris International e.a.v. Commission, Joined Cases T-377/oo, T-379/oo, T-380/oo, T-26o/01 \& T-272/01, EU:T:2003:6.

${ }^{22}$ See Opinion 1/13 of the Court of 14 October 2014 given pursuant to Article 218(11) TFEU on the Convention on the civil aspects of international child abduction, EU:C:2014:2303.

${ }^{23}$ F. Coman-Kund, op. cit., p. 103. This is not to say that the lack of a Treaty legal basis necessarily results in the illegality of these instruments.

${ }^{24}$ Some examples of external action instruments regularly used by the Commission that are not explicitly foreseen in the Treaties are opinions, recommendations, declarations, reports, MoUs, working arrangements, etc. Examples of agreements concluded outside of the framework in Article 218 TFEU by the Commission have varying terminology, for instance financial administrative framework agreement, framework agreement, administration agreement, contribution agreement, monetary agreement, etc. F. Coman-Kund, op. cit., p. 109, 121.
}

25 Ibid., pp. 105, 121. 
Turning to administrative agreements, Article 218 TFEU refers to international agreements in a general sense. ${ }^{26}$ This means that the formal denomination of an instrument is not relevant and that, for instance, a binding (administrative) agreement taking the form of an MoU, on which the Commission relies in the field of competition policy, should still be concluded in accordance with Article 218 TFEU. However, can and should the same procedure also be applied to the conclusion of a non-binding administrative arrangement? Is there any scope for the European Commission (or for EU agencies) to conclude such instruments on behalf of the Union? Alternatively, can the European Commission or another EU organ conclude international agreements binding only on themselves? Which legal basis in the Treaties would confer such a power? These questions have been partially addressed by the Court of Justice in the France $v$. Commission cases and in the recent Council $v$. Commission case.

\section{France v Commission: keeping the Commission on a leash}

In France $v$ Commission I the Court was asked to determine whether the Commission had the competence to conclude administrative agreements on behalf of the EU. The Commission thought it did in so far as these agreements (i) created only limited obligations which can be discharged by the Commission alone; (ii) did not have an impact on the EU budget and (iii) did not result in the liability of the Union in case of non-performance (non-performance in this case only resulting in the termination of the agreement). ${ }^{27}$ Both Advocate General (AG) Tesauro and the Court of Justice rejected the reasoning of the Commission finding that no (administrative) agreements binding on the EU could be concluded by EU organs unless the rather heavy procedure of Article 218 TFEU is used. However the Court's ruling did not make the need for greater inter-agency cooperation and coordination disappear. As Coman-Kund finds: '[i]n spite of the ban [...], the Commission practice of concluding international cooperation instruments of a technical-administrative nature [...] has continued'. ${ }^{28}$ Since the necessary inter-agency cooperation and coordination could not be formalised (on the EU part) through binding administrative agreements, the question arose whether the EU Treaties left a scope for non-binding administrative arrangements concluded by the Commission or other EU organs on their own behalf or possibly binding administrative agreements to which the Commission or the EU organ, but not the Union, is a party.

\footnotetext{
${ }^{26}$ Opinion 1/75 of the Court of 11 November 1975 given pursuant to Article 228 of the EEC Treaty, EU:C:1975:145, 'The formal designation of the Agreement envisaged under international law is not of decisive importance in connexion with the admissibility of the Request. In its reference to an 'agreement', the second subparagraph of Article 28(1) of the Treaty uses the expression in a general sense to indicate any undertaking entered inti by entities subject to international law which has binding force, whatever its formal designation.'

${ }^{27}$ Ibid., paragraph 30.

${ }^{28}$ F. Coman-Kund, op. cit., p. 159.
} 
France $v$. Commission II can indeed be read as permitting the former practice. ${ }^{29}$ Ten years following France $v$. Commission I, the two parties faced each other again before the Court over another autonomous Commission action. This time the Commission had concluded Guidelines on its own behalf with its US counterpart. France argued that the Guidelines were binding and that the Commission had therefore again acted ultra vires. The Court found the Guidelines non-binding, but immediately added that this did not make the Commission competent to conclude them. Instead, in absence of any explicit provision on the issue in the Treaties, the institutions must respect the general 'division of powers and the institutional balance established by the Treaty'.$^{\circ}$ The Court in casu accepted the Commission exercising this competence because it had acted within the policy framework set by the Council and because the Commission had respected the principle of sincere cooperation by keeping the Article 133 EC (now Article 207 TFEU) committee informed.

Strictly abiding to the interpretation of the Court in the France $v$. Commission cases would imply that technical-administrative arrangements concluded outside Article 218 TFEU can only be valid if they are non-binding and respect the institutional balance, which would mean that binding agreements concluded by the Commission or EU agencies on behalf of the EU, in absence of a clear enabling clause, are in breach of Article 218 TFEU. This would in turn imply that any international agreement binding the EU, no matter how minor or technical its content, should be concluded in accordance with the heavy procedure of Article $218 \mathrm{TFEU}$. A special situation is the one under Article 335 TFEU which allows the EU institutions (but not the EU bodies, offices and agencies) to represent themselves externally by virtue of their administrative autonomy. ${ }^{31}$ This allows them to assume obligations (binding only on themselves) although it is unclear which situations may be covered by the Article. This view is also taken by the Council Legal Service, which clarified that if the content of an agreement such as an MoU is limited to administrative issues for practical cooperation between an EU institution and a third country or organisation, Article 335 TFEU applies. In such a situation it will be the EU institution that commits itself, not the Union. ${ }^{32}$

\section{Further delineation of permissible Commission action in Council v Commission}

The limits of the Commission's power to act externally, which are also relevant for agency external action, were further clarified in Case C-66o/13. The case marked the first time that the Council challenged the Commission's practice of entering into non-

\footnotetext{
29 Judgment in France $v$ Commission II, EU:C:2004:173.

30 Ibid., paragraph 40.

31 'The Union shall be represented by each of the institutions, by virtue of their administrative autonomy, in matters relating to their respective operation.'

$3^{2}$ Council of the European Union, Contribution of the legal service on the 'Procedure to be followed for the conclusion by the EU of Memoranda of Understanding, Joint Statements and other texts containing policy commitments, with third countries and international organisations' Brussels, 1 February 2013, 5707/13.
} 
binding arrangements on behalf of the EU before the Court. The Council in casu asked for the annulment of the 2013 Commission decision on the signature of an Addendum to the 2006 Memorandum of Understanding on a Swiss financial contribution to the new Member States. 33 The Council in this manner took action against a perceived increased tendency of the Commission to sign non-binding instruments containing EU policy commitments. 34

While Switzerland is not a member of the EU, it has access to the internal market based on a series of bilateral agreements. 35 In return for this access to the internal market, Switzerland agreed to make a financial contribution to reduce economic and social disparities within the enlarged Union. This commitment was formalized in a (nonbinding) ${ }^{36} \mathrm{MoU}$ with the EU in 2006,37 in which Switzerland undertakes to conclude (binding) bilateral agreements with the 'new' EU Member States, whereby those agreements 'must be in conformity with the guidelines laid down in the Memorandum'. ${ }^{8}$ The MoU was signed on the part of the EU, by both the Council Presidency and by the Commission. ${ }^{39} \mathrm{~A}$ first addendum to the MoU, to include Bulgaria and Romania in the financial mechanism, was concluded in 2008 and signed by the same parties as the original MoU.40 At the end of 2012 the Commission was again mandated by the Council, and the Member States meeting within the Council, to engage in the necessary negotiations on the adaptation of the Swiss financial contribution in light of the imminent EU accession of Croatia. However, unlike the previous addendum, the 2013 addendum was signed by the Commission alone, on behalf of the EU.

According to the Commission, the Council's 2012 conclusions constituted a political decision in the sense of Article 16 TEU, ${ }^{41}$ allowing it not only to negotiate but also to

33 Commission Decision C(2013) 6355 final of 3 October 2013 on the signature of the Addendum to the Memorandum of Understanding on a Swiss financial contribution.

34 Opinion of Advocate General Sharpston in Council v Commission, EU:C:2015:787, paragraph 79. The Council, however, only refers to two examples, namely the Joint Statement on Space Technology Cooperation with China and the MoU on the establishment of a Strategic Partnership between the EU and the International Fund for Agricultural Development of 2012. Another might be the Joint Declaration on relations between the European Union and Greenland and Denmark of 2015.

35 On these agreements, see M. Maresceau, EU-Switzerland: Quo Vadis?, (2011) 39 Georgia Journal of International and Comparative Law 3, pp. 729-737.

${ }^{36}$ See Opinion of Advocate General Sharpston in Council $v$ Commission, C-66o/13, EU:C:2015:787, paragraph 32.

37 For the text of the MoU, see Conclusions of the Council of the European Union and of the Representatives of the Governments of the Member States meeting within the Council on a financial contribution by the Swiss Confederation, 14 February 2006, Doc. 6283/o6.

${ }^{38}$ See ibid. p. 9.

39 Ibid., p. 3.

40 See Conclusions of the Council of the European Union and of the Representatives of the Governments of the Member States meeting within the Council on an Addendum to the Memorandum of Understanding between the President of the Council of the European Union and the Swiss Federal Council of 27 February 2006, 5 May 2008, Doc. 8681/o8.

${ }^{41}$ Opinion of Advocate General Sharpston in Council $v$ Commission, EU:C:2015:787, paragraph 40. 
conclude the addendum with Switzerland. As a result, the Commission did not request the Council's (or the Member States') prior approval,42 although it did keep the EFTA Working Party of the Council informed of the result of the negotiations. The legal basis cited by the Commission's decision was Article 17 TEU, 43 which gives the Commission a general competence to represent the EU internationally and to perform coordinating, executive and management tasks.

The Council applied for the annulment of the decision based on two pleas in law. Firstly, it claimed that the Commission disrespected the distribution of powers between the Council and the Commission (principle of conferral) and therefore also the principle of institutional balance with regard to the approval and signature of a non-binding agreement between the Union and a third State. Secondly, the Council reproached the Commission with having violated the principle of mutual sincere cooperation.

To argue its first plea, the Council invoked the 2004 France $v$. Commission case, 44 where the Court ruled that '[d]etermining the conditions under which such a measure may be adopted requires that the division of powers and the institutional balance established by the Treaty [...] be duly taken into account'. 45 The Council argued that by unilaterally accepting the Addendum on behalf of the Union, without asking its authorization, the Commission had indeed disregarded this division of powers. 46

According to the Council, Article 218 TFEU reflects the distribution of powers under Article 16 and 17 TEU, conferring onto the Council the power to define Union policy in external relations. This would imply that the Council authorises negotiations and approves the political commitments that the Union enters into with third States or international organisations. The formal inapplicability of Article 218 TFEU would therefore not preclude the Council's involvement. According to the Council signing an international agreement implies the Union's acceptance of a content that cannot be predicted ex ante and therefore cannot be considered an 'established position'.47

The Commission, by contrast, considered that its signature of the Addendum was no more than an act of external representation according to Article 17(1) TEU on a political

\footnotetext{
42 Ibid., paragraph 42. Since the Commission was of the opinion that the 2012 conclusions were Council conclusions (hybrid acts not being possible), it need not require the consent of the Member States in any case.

43 Ibid., paragraph 41.

44 Judgment in France v Commission II, EU:C:2004:173, paragraphs 38-46.

45 Ibid., paragraph 40.

${ }^{46}$ Leuven Centre for Global Governance Studies, Working Paper No. 156 - March 2015, Charting the Legal Landscape of EU External Relations Post-Lisbon, Thomas Ramopoulos, Jan Wouters, 14-15.

47 Opinion of Advocate General Sharpston in Council v Commission, EU:C:2015:787, paragraphs 89-91.
} 
position previously fixed by the Council..$^{8}$ In casu the Commission put forward that the contested decision did not diverge from the Union's position on the financial contribution for Croatia set out in the 2012 conclusions and that there was no margin of discretion on the matter for the Commission.

The Court in its judgment is silent on the application of Article 218 TFEU and whether that Article reflects the general distribution of powers among the institutions. It did emphasise that the 2012 conclusions only authorised the Commission to initiate negotiations, but these in no way allowed the signature of the resulting addendum on behalf of the Union. It then rather bluntly concluded that 'the Commission cannot be regarded as having the right, by virtue of its power of external representation under Article 17(1) TEU, to sign a non-binding agreement resulting from negotiations conducted with a third country'. 49 The Court thus annulled the Commission's decision for infringement of the principle of distribution of powers and the principle of institutional balance.

The Court's reasoning may create some confusion, because it is unclear whether the Council could have nonetheless conferred such a power (in casu in its 2012 conclusions) on the Commission, where the Commission does not derive such a power from Article 17 TEU itself.50 It follows from Council $v$. Commission that the decision to sign even a non-binding agreement may constitute the making of Union policy and therefore falls under Article 16 TFEU, because it requires an assessment of whether the agreement (as it results from the negotiations) still reflects the Union's interests. ${ }^{1}$ This holds true even when 'the content of a non-binding agreement negotiated by the Commission with a third country corresponds to the negotiating mandate given by the Council [...]' ${ }^{52}$

${ }^{48}$ The Commission more precisely contended that the 2013 Addendum in its recitals refers to the Council's position to negotiate with Switzerland on the financial contribution for Croatia and to invite the Commission to start those negotiations, and referred to its reaction that the 2012 conclusions were to be understood as a political decision of the Council under Article 16 TEU and that it accepted, on that basis, to engage in discussions with Switzerland on behalf of the Union. Recital 5 states that the Addendum reflects the Union's position as expressed in the 2012 conclusions, in turn building on the $2006 \mathrm{MoU}$ and 2008 Addendum. In line with that position, it is mentioned that the proposed Addendum reflects the Swiss political engagement to negotiate with Croatia an agreement on a financial contribution similar to what was decided for the previous beneficiaries and calculated in proportion to the original Swiss financial contribution without any financial implications for the EU budget. (Opinion of Advocate General Sharpston in Council v Commission, EU:C:2015:787, paragraphs 44, 94-95.)

49 Judgment in Council v Commission, C-66o/13, EU:C:2016:616, paragraph 38.

${ }_{50}$ The Council Legal Service's observation in para. 20 of its opinion on the signature by the Commission, on behalf of the European Union, of a Joint Statement on Space Technology Cooperation between the European Union and the People's Republic of China could also be read in this light. See Council of the European Union, 6 November 2012, Doc. 15809/12.

${ }^{51}$ Judgment in Council $v$ Commission, EU:C:2016:616, paragraphs 40-42.

$5^{2}$ Ibid., paragraph 43. 


\section{Administrative agreements in the wake of Council v Commission}

Council $v$. Commission has further filled in the blanks with regard to the existence of administrative agreements in the EU legal order, and completed the picture painted earlier by the France $v$ Commission cases:

Table 1: Agreements concluded by EU organs outside Article 218 TFEU

\begin{tabular}{|l|l|l|}
\cline { 2 - 3 } \multicolumn{1}{c|}{} & Binding & Non-binding \\
\hline \multirow{2}{*}{ On EU's behalf } & France $v$. Commission I & \multirow{2}{*}{ Council v Commission C-660/13 } \\
\cline { 2 - 3 } & Article 220 TFEU53 & \\
\hline On authority's behalf & Article 335 TFEU & France v. Commission II \\
\hline
\end{tabular}

In principle, EU organs cannot conclude agreements binding on the Union outside the procedure laid down in Article 218 TFEU. EU institutions can avoid this situation in the event that Article 335 TFEU applies and to conclude agreements binding only on themselves. Even when an agreement is non-binding, the EU's organs cannot enter into such an agreement on the EU's behalf. The Court in Council v. Commission does seem to allow this possibility in case the Council would grant the Commission a mandate, but this would have to be done explicitly, since the Commission does not derive such a competence from Article 17 TEU itself. This may be linked with a well-established practice whereby the Commission is empowered in secondary law (international agreements or legislative acts) to conclude agreements with third countries on behalf of the EU. Bartelt and Ott note that the legality of this practice i.a. depends on continued respect for the institutional balance and on the non-political nature of the commitments entered into by the Commission, 54 i.e. the EU's policy should be defined by the Council (and Parliament) as confirmed in Council v. Commission.

\section{Scrutinizing provisions in EU agencies' establishing acts}

A cursory look at the establishing acts of a selection of agencies reveals that the EU legislator has devoted insufficient attention to the constitutional limits to external agency action as described above. At the same time, some sign of a changing practice may also be noted.

53 On the possible use of Article 220 TFEU, see S. Bartel and A. Ott, 'Die Verwaltungszusammenarbeit der Europäischen Kommission mit Drittstaaten und internationalen Organisationen: Kategorisierung und rechtliche Einordnung, (2016) 51 Europarecht Beiheft 1, pp. 150-152. 54 Ibid., p. 158. 
The regulations establishing the European Supervisory Authorities (ESAs) 55 only show a concern that the international activity of the agencies will not 'prejudice the competences of the Member States and the institutions' and will not 'create legal obligations in respect of the Union and its Member States'. ${ }^{56}$

By contrast, the regulation establishing the European Aviation Safety Agency (EASA) does not emphasize the Member States' or EU institutions' competences. Instead, it provides that the EASA shall assist the Community and the Member States and that it may conclude working arrangements 'in accordance with the relevant provisions of the Treaty'. ${ }^{57}$ The latter provision is rather enigmatic, but the regulation further provides that EASA working arrangements should receive prior Commission approval. 58 The proposal for a new EASA regulation provides that the EASA will assist the Commission, rather than the EU or the Community, and has dropped the above noted enigmatic provision. It also retains the requirement of prior Commission approval.59

Whereas the old European Railway Agency (ERA) regulation did not contain an enabling clause, the new regulation contains a rather elaborate one. ${ }^{60}$ It provides that the ERA can enter into agreements or arrangements '[i]n so far as is necessary in order to achieve the objectives set out in [the ERA] Regulation' and without prejudice to the competences of the Member States, the institutions, or the EEAS. ${ }^{61}$ The ERA regulation also explicitly specifies the purpose of such working arrangements: 'to keep up with scientific and technical developments and to ensure promotion of the Union railways legislation and standards'.62 As regards procedure, the ERA regulation merely requires prior discussion with and periodic reporting to the Commission. The regulation further provides that the ERA Management Board must adopt a strategy for the ERA's relations with third countries and international organisations 'concerning matters for which the

55 European Banking Authority, European Insurance and Occupational Pensions Authority, European Securities and Markets Authority.

${ }^{6}$ See Articles 33 of Regulation 1093/2010 of the European Parliament and of the Council establishing a European Supervisory Authority, OJ 2010 L 331; Regulation 1095/2010 of the European Parliament and of the Council establishing a European Supervisory Authority, OJ 2010 L 331; Regulation 1095/2010 of the European Parliament and of the Council establishing a European Supervisory Authority, OJ 2010 L 331.

57 Article 27(2) of Regulation 216/2008 of the European Parliament and of the Council on common rules in the field of civil aviation and establishing a European Aviation Safety Agency, OJ 2080 L 79. $5^{8}$ EASA Regulation, Article 27(2).

${ }^{59}$ See Proposal for a Regulation of the European Parliament and of the Council on common rules in the field of civil aviation and establishing a European Union Aviation Safety Agency, and repealing Regulation (EC) No 216/2008 of the European Parliament and of the Council, COM(2015) 613 final. ${ }^{60}$ See Article 44 of Regulation (EU) 2016/796 of the European Parliament and of the Council of 11 May 2016 on the European Union Agency for Railways and repealing Regulation (EC) No 881/2004, OJ L 2016 138. (New ERA Regulation)

${ }^{61}$ New ERA Regulation, Article 44(1).

62 Ibid. 
Agency is competent'. ${ }^{63}$ This provision may be construed as also requiring the agencies' working arrangements to be confined to 'matters for which the ERA is competent'.

The old Frontex ${ }^{64}$ regulation made a distinction between arrangements concluded with international organisations and arrangements concluded with third states. In relation to both, the regulation contained the same enigmatic provision as the EASA regulation. ${ }^{65}$ For arrangements concluded with third states, it further provided that they 'be purely related to the management of operational cooperation'. ${ }^{66}$ Procedurally the regulation prescribed that the Commission ought to give its prior opinion and that the Parliament be fully informed as soon as possible (for arrangements concluded with international organisations Frontex 'shall inform the European Parliament'). ${ }^{67}$ The new Frontex regulation adds a number of changes:

- The Commission's prior approval is required before Frontex concludes arrangements with international organisations or third countries.

- The enigmatic provisions on 'arrangements concluded in accordance with the relevant provisions of the Treaty' are dropped.

- Cooperation with third countries will be pursued in coordination with the Union delegations.

- The working arrangements must be 'in accordance with Union law and policy' and 'shall specify the scope, nature and purpose of the cooperation and be related to the management of operational cooperation'.

- Frontex must inform the Parliament before a working arrangement with a third country is concluded.

Finally, the recent EU Agency for Law Enforcement Training (CEPOL) regulation may also be illustrative of a changing practice. ${ }^{68}$ Whereas the old CEPOL decision required prior Council approval before cooperation agreements with third country bodies could be concluded, ${ }^{6} 9$ the new regulation provides that the agreements must be authorized by the Management Board following prior consultation with the Commission. ${ }^{70}$

\footnotetext{
63 Ibid., Article 44(3).

${ }^{64}$ European Agency for the Management of Operational Cooperation at the External Borders.

65 Regulation (EU) No 1168/2011 of the European Parliament and of the Council of 25 October 2011 amending Council Regulation (EC) No 2007/2004 establishing a European Agency for the Management of Operational Cooperation at the External Borders of the Member States of the European Union, OJ L 304, 22.11.2011, Article 13.

66 Old Frontex Regulation, Article 14(2).

${ }^{67}$ Ibid., Article 13.

68 Regulation (EU) 2015/2219 of the European Parliament and of the Council of 25 November 2015 on the European Union Agency for Law Enforcement Training (CEPOL) and replacing and repealing Council Decision 2005/681/JHA, OJ L 319, 4.12.2015.

69 Council Decision 2005/681/JHA of 20 September 2005 establishing the European Police College (CEPOL) and repealing Decision 2000/820/JHA, OJ L 256, 1.10.2005, Article 8(3).

${ }^{70}$ New CEPOL Regulation, Article 9 (1) (r).
} 
Already from this small selection of legislative acts it is clear that the rules on EU agencies' 'treaty-making power' are very heterogeneous and that in legislative practice, the institutions are elaborating increasingly detailed provisions on the scope of the agencies' external action. While this is to be lauded, the EU legislator should still be more consistent in drafting the provisions framing the agencies' external relations and preferably should generally set out an explicit strategy in this regard, something which the Common Approach still lacks. 


\begin{tabular}{|c|c|c|c|c|c|c|c|c|c|c|c|}
\hline$\frac{\frac{c}{0}}{\frac{0}{2}}$ & $\begin{array}{l}\text { Arrangements } \\
\text { concluded in } \\
\text { accordance } \\
\text { with the } \\
\text { relevant } \\
\text { provisions of } \\
\text { the Treaty }\end{array}$ & $\begin{array}{l}\text { Without } \\
\text { prejudice to } \\
\text { MS', } \\
\text { institutions', } \\
\text { (EEAS') } \\
\text { competences }\end{array}$ & $\begin{array}{l}\text { Shall not } \\
\text { bind the } \\
\text { EU or MS }\end{array}$ & $\begin{array}{l}\text { Shall not } \\
\text { prevent MS } \\
\text { from } \\
\text { concluding } \\
\text { agreements }\end{array}$ & $\begin{array}{l}\text { Within } \\
\text { agency } \\
\text { mandate }\end{array}$ & $\begin{array}{l}\text { In so far as } \\
\text { necessary } \\
\text { to fulfil } \\
\text { mandate }\end{array}$ & $\begin{array}{l}\text { Identification } \\
\text { of purpose of } \\
\text { the } \\
\text { agreements }\end{array}$ & $\begin{array}{l}\text { Prior } \\
\text { Council } \\
\text { approval }\end{array}$ & $\begin{array}{l}\text { Prior } \\
\text { Commission } \\
\text { approval }\end{array}$ & $\begin{array}{l}\text { Prior } \\
\text { Commission } \\
\text { opinion }\end{array}$ & $\begin{array}{l}\text { Parliament } \\
\text { information }\end{array}$ \\
\hline \multirow{8}{*}{ 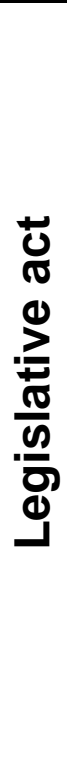 } & \multirow[t]{2}{*}{$\begin{array}{l}\text { Current } \\
\text { EASA }\end{array}$} & & & & & & & & $\begin{array}{l}\text { Current } \\
\text { EASA }\end{array}$ & & \\
\hline & & & & & & & & & $\begin{array}{l}\text { EASA } \\
\text { proposal }\end{array}$ & & \\
\hline & \multirow[t]{2}{*}{ Old Frontex } & & & & & & Old Frontex & & & Old Frontex & Old Frontex \\
\hline & & & & & $\begin{array}{l}\text { New } \\
\text { Frontex }\end{array}$ & & $\begin{array}{l}\text { New Frontex } \\
\text { (stricter) }\end{array}$ & & $\begin{array}{l}\text { New } \\
\text { Frontex }\end{array}$ & & $\begin{array}{l}\text { New Frontex } \\
\text { (for } 3 d \\
\text { countries prior } \\
\text { to conclusion) }\end{array}$ \\
\hline & & ESAs & ESAs & ESAs & & & & & & & \\
\hline & & New ERA & New ERA & New ERA & New ERA & New ERA & New ERA & & & New ERA & \\
\hline & & & $\begin{array}{l}\text { New } \\
\text { CEPOL }\end{array}$ & & & & & & & $\begin{array}{l}\text { New } \\
\text { CEPOL }\end{array}$ & \\
\hline & & & & & & & & $\begin{array}{l}\text { Old } \\
\text { CEPOL }\end{array}$ & & & \\
\hline
\end{tabular}




\section{Possibilities for EU agency action}

The extent to which EU agencies can enter into agreements or arrangements with third countries or international organisations is determined by a combined application of the limits discussed in sections 3 to 5 . As a result, the limits to the Commission's external powers should at the same time be the outer limits to the agencies' external powers. The latter should furthermore also comply with the Meroni doctrine as re-interpreted by the Court in Short-selling, meaning agencies can only exercise precisely delineated external powers.

Thus, EU agencies would be precluded from entering into binding agreements on behalf of the Union, since such agreements come under Article 218 TFEU, as clarified by the Court in France $v$. Commission I. Council $v$. Commission adds to this that EU agencies are also prohibited from entering into non-binding agreements on behalf of the EU. It might be argued that EU agencies could still be empowered under secondary law, analogously to the Commission, but the political institutions have shut this door firmly in the Common Approach. ${ }^{71}$ In any event, it would appear legally difficult to transpose this institutional practice from the Commission to the EU agencies, given that the latter are not provided for under primary law and that the power to bind the EU as a whole is of significant constitutional importance.

At the same time Council $v$. Commission could be read as suggesting that the Court would indeed allow for a delegation of international treaty powers to the Commission. Earlier Schütze found this only theoretically possible, since the Lisbon Treaty only dealt expressly with the issue of delegation in Articles 290 and 291 TFEU, whereby 'international powers fall in between [both Articles]',72 meaning there was no apparent legal basis for such a delegation. In the meantime however, Short-selling has taught us that Articles 290 and 291 TFEU form an open system and even allow delegations or conferrals to EU agencies. As a result, a delegation of international treaty powers to EU agencies cannot be ruled out anymore, albeit that these arrangements or agreements could only be concluded on the EU agency's own behalf.

Generalising France $v$. Commission II, the institutional balance ought to be safeguarded regardless of whether EU agencies enter into binding or non-binding agreements. However, whether the limits flowing from the Meroni doctrine would also apply to non-binding agreements is less apparent. After all, it should be noted that having the EU agencies exercise soft law powers internally (in the EU) has been one way of circumventing the chilling effects of the Meroni doctrine.73 This would mean

${ }^{71}$ Common Approach, point 25.

${ }^{72}$ Robert Schütze, Foreign affairs and the EU constitution: selected essays, 2014, Cambridge University Press, p. 195.

${ }^{73}$ See i.a. Simone Gabbi (2009) 'The European Food Safety Authority : judicial review by community courts', European Journal of Consumer Law 1, p. 175. Similarly, see Jacopo Alberti (2014) 'L'utilisation d'actes de soft law par les agences de l'Union européenne', RUE 576, p. 162. 
that when entering into binding agreements EU agencies should respect the institutional balance and their powers should be precisely delineated, whereas when they enter into non-binding arrangements they should respect the institutional balance without necessarily being restricted to exercising only precisely delineated powers. Of course, this does not mean that they could adopt any kind of non-binding agreement. Following the principles of conferral and proportionality, (i) the power to enter into agreements (including non-binding ones) should be expressly provided; (ii) such agreements can only relate to matters covered by the enabling legislative act and (iii) any agreement can only be entered into if necessary for the agency to achieve the objectives of its mandate.

Two major questions are raised by the above: precisely which requirements flow from the institutional balance and how do they relate to the (Meroni) requirement that the powers conferred on agencies ought to be precisely delineated?

Le Bot has argued that the key function of the principle of institutional balance is that of systemic protection, safeguarding the prerogatives of the institutions. ${ }^{74}$ In the original Meroni ruling this concern was alien to the 'balance of powers', which had a function of protecting private parties and requires that the delegate bodies have to be controlled by the Treaty mandated institutions. In Short-selling, the Court found that the essence of Meroni requires that only precisely delineated powers are conferred on agencies, but it was completely silent on the political control exercised by the EU institutions, mentioning only judicial control.

The problematic nature between the two requirements is further clarified if one takes into account the Court's recent jurisprudence on external relations. France $v$. Commission II requires the institutional balance to be respected even if an administrative body concludes a non-binding agreement on its own behalf. From ITLOS75 and Council v. Commission it follows that respect for the institutional balance requires the Council's prerogatives under Article 16(1) TEU (the policy-making function) to be respected. As a result, whether concluding a binding or a non-binding agreement, EU agencies cannot autonomously work out a policy, but must respect the policy set by the EU institutions. What does it then practically mean that agencies are not restricted to exercising only precisely delineated powers when they enter into nonbinding agreements but, when doing so, they should still respect established EU policy set by the Council?

Arguably, the principle of institutional balance does not only require that the Council's policy function is being respected but also the Commission's prerogative to 'ensure the Union's external representation'. ${ }^{76}$ In addition, although Article 218 TFEU does not

${ }^{74} \mathrm{~F}$. Le Bot (2012) Le principe de l'équilibre institutionnel en droit de l'union européenne, Paris, Université Panthéon-Assas, PhD Thesis, p. 243. See also M. Chamon (2015) 'The Institutional Balance, an Ill-Fated Principle of EU Law?', European Public Law 2, p. 281.

75 Judgment in Council v. Commission (ITLOS), EU:C:2015:663.

${ }^{76}$ See Article 17(1) TEU. 
apply to agreements concluded by EU agencies, it could be argued that Article 218(10) TFEU, requiring the 'Parliament [to] be immediately and fully informed at all stages of the procedure', gives specific expression to a general prerogative of the Parliament.

\section{Drafting legislative provisions in light of the constitutional limits to external agency action}

Relying on the selection of legislative acts above, it is laudable that the new Frontex regulation and the EASA proposal omit the reference to agency action 'in accordance with the relevant provisions of the Treaty' since this provision did not clarify much. The inclusion of provisions stating that 'agency action cannot prejudice the Member States' or the institutions competences and cannot bind them give expression to the principles of conferred powers and institutional balance' is equally to be welcomed.

Which provisions ensure that EU agencies respect the Meroni doctrine when acting externally? As noted above, the Short-selling ruling seems to emphasize three elements in this doctrine: (i) empowering an agency should be exceptional, (ii) the agency's powers should be embedded in decision-making procedures involving other actors, (iii) the agency should act pursuant to pre-defined criteria. The latter element is reflected in the new ERA and Frontex' regulation providing that the agencies should act within their mandate and prescribing the purpose of the agreements. However, only the new ERA regulation contains a provision which reflects the first element, prescribing that the agency should only act externally in so far as necessary to achieve its mandate, which can also be seen as ensuring compliance with the proportionality principle. Finally, it could be argued that the second element in the doctrine is met when the Commission is asked to give an opinion on an agreement. However, while this mere power of opinion would be sufficient to ensure compliance with Meroni, this may not be the case for ensuring compliance with the institutional balance. The latter (i.a.) requires the Commission's prerogatives to be respected, begging the question whether the Commission ought not be granted with a veto power over these agreements, as is prescribed in the EASA regulation and the new Frontex regulation.

Further institutional balance issues may be noted in relation to the other EU institutions. While the right of information of the Parliament, enshrined in Article 218(10) TFEU, is zealously enforced by the Court in its (recent) jurisprudence, 77 it is remarkable that only the Frontex regulation imposes this obligation on an agency. In light of the institutional balance this should be generalized for all agencies.

Finally, under Article 16 TEU it is the Council's prerogative to define the EU's policy. It is doubtful whether the restriction on the agencies' capacity to bind the EU and the provisions confirming that the agencies cannot affect the Member States' and the institutions' competences are sufficient in this regard. In addition, it would seem that an agency can still develop policies not covered by the Council's approval while fully

${ }_{77}$ See Judgment of 24 June 2014, Parliament $v$ Council, C-658/11, EU:C:2014:2025. 
respecting the new Meroni doctrine. The Council prerogatives could be safeguarded here by firstly restricting an agency's external action to what is required in order to fulfil its mandate (as co-defined by the Council in the agency's basic legislative act) and by providing for Council approval of agency's agreements. Alternatively, the Council could also delegate this power of approval to the Commission. After all, if it follows from Council v. Commission that the Council may delegate treaty-making power to the Commission, it should a fortiori follow that the Commission may be delegated the power to veto such agreements to be concluded by other bodies. This solution appears more attractive than imposing a heavy requirement such as Council approval for agreements that should essentially be technical or administrative in nature.

\section{Concluding remarks and remaining questions}

In light of the above analysis it is to be lauded that the institutions in recent legislative practice are devoting more attention to the framework for agencies' external relations, going beyond the insufficient requirements flowing from the Common Approach.

Simultaneously the provisions to be found in recent legislative acts are still very much heterogeneous and no single legislative act properly imposes a complete framework on its agency, ensuring respect for all constitutional limits (conferred powers, proportionality, institutional balance, Meroni).

A pertinent question from this perspective is how detailed such a framework should be, given that it should not be so rigid that effective external agency action becomes impossible. In this sense, should the legislator make an explicit distinction between binding and non-binding agreements to be concluded by the agency, or should this be left in abeyance?

Further to this, does it indeed make sense to restrict the applicability of Meroni to binding agreements concluded by agencies and would there be any practical consequences of Meroni not being applicable to non-binding agreements? Or has the Meroni doctrine been hollowed out to such an extent that it does not impose a further limit than those already imposed by the constitutional principles of conferred powers, proportionality and institutional balance?

Finally is it satisfactory and legally correct to represent the Commission's veto power over agencies' agreements as a power (partially) delegated to it by the Council in order to ensure that agencies do not intrude on the Council's policy making function and (partially) conferred on the Commission by the legislator to safeguard its own prerogatives under the institutional balance? 